\title{
Adoptive Immunotherapy after Allogeneic Hematopoietic Progenitor Cell Transplantation: New Perspectives for Transfusion Medicine
}

\author{
Susanne Hofmann Jochen Greiner \\ Department of Internal Medicine III, University of UIm, Germany
}

\section{Keywords}

Allogeneic stem cell transplantation $\cdot \mathrm{DLI} \cdot \mathrm{GVL} \cdot \mathrm{T}$ cell

\section{Summary}

Allogeneic hematopoietic progenitor cell transplantation (HPCT) is a crucial therapeutic option in hematological malignancies, and the graft-versus-leukemia (GvL) effect builds the cornerstone of a long-lasting remission. Cytotoxic $T$ cells are known to be the primary effector cells in GvL. They recognize minor histocompatibility antigens (mHags) and tumor/leukemia-associated antigens. In case of disease relapse after HPCT, donor lymphocyte infusion (DLI) is an important treatment option for re-induction of remission. However, both treatments, HPCT and DLI carry the risk of morbidity and mortality due to graft-versus-host disease (GvHD) and severe infections. Therefore, the development of targeted adoptive immunotherapy with a lower risk of GvHD is needed, and several study groups are working on that topic.

\section{Introduction}

There are several variants of immunotherapy in the treatment of cancer. They can be differentiated into humoral forms such as monoclonal antibodies (e.g., anti-CD20) or the use of immune adjuvants (e.g., IL-2) and into cellular

\section{KARGER}

Fax +497614520714

Information@Karger.de

www.karger.com
๑) 2011 S. Karger GmbH, Freiburg forms such as vaccination strategies (peptide, dendritic cell vaccination) and adoptive cell transfer (ACT). The different types of ACT, especially considering the use and possibilities of this treatment modality after hematopoietic progenitor cell transplantation (HPCT), are reviewed in this article.

Schlüsselwörter

Allogene Stammzelltransplantation · DLI · GvL · T-Zellen

\section{Zusammenfassung}

Von der allogenen Blutstammzelltransplantation (HPCT) bei malignen hämatologischen Erkrankungen ist bekannt, dass der Spender-gegen-Leukämie(GvL)-Effekt die Grundlage für einen langfristigen Heilerfolg bildet. Dieser GvL-Effekt ist überwiegend vermittelt durch zytotoxische T-Zellen, die Minor-Histokompatibilitätsantigene (mHags) sowie Tumor/Leukämie-assoziierte Antigene erkennen. Bei einem Rezidiv nach allogener Stammzelltransplantation ist die Spenderlymphozytengabe (DLI) zur Remissionsinduktion eine sehr wichtige Therapieoption. Jedoch bergen beide Behandlungen, HPCT und DLI, das Risiko der Morbidität und Mortalität durch die Spender-gegen-Empfänger(GvHD)-Reaktion und Infektkomplikationen. Aus diesem Grund ist die Entwicklung von zielgerichteten Immuntherapien mit möglichst geringem GvHD-Risiko nötig und wird von verschiedenen Arbeitsgruppen intensiv erforscht. 


\section{Adoptive Cell Transfer in General}

The basic concept of ACT is to identify cancer-reactive lymphocytes, harvest those from a cancer patient, stimulate them ex vivo, expand the antitumor lymphocytes ex vivo and reintroduce them into the patient in order to enhance the antitumor effect of the cells $[1,2]$. Peripheral blood, tumor biopsies, malignant effusions and resected lymph nodes are the sources for T cells used for autologous ACT. The use of antigen-specific CD8+ cytotoxic T cells (CTLs) derived from peripheral blood lymphocytes is a widely clinically tested method in ACT for cancer [1,2].

The application of tumor-infiltrating lymphocytes (TILs) isolated from fresh tumor biopsies appears promising when reinfused into the patient after lymphoablative chemotherapy $[3,4]$. Especially the TIL strategy is a technical challenge and labor- and time-intensive. T-cell counts strongly vary in the different biopsies that are taken, and only one third contains enough $\mathrm{T}$ cells to proceed with ex vivo activation and expansion. The full process until reinfusion takes about 6 weeks and needs stimulation cultures with OKT3 (anti-human CD3 monoclonal antibody), irradiated allogeneic feeder peripheral blood mononuclear cells and IL-2 [5].

A further development of ACT is the use of engineered T cells. Those could be the source of choice if the number of TILs in a biopsy is too low to perform TIL infusion or if the tumor is poorly antigenic. $\mathrm{T}$ cells are engineered to express tumor antigen-specific receptors; alternatively chimeric tumor antigen- specific receptors, so-called $\mathrm{T}$ bodies, have been constructed. $\mathrm{T}$ bodies express an extracellular ligand-binding domain derived from an antibody and an intracellular signaling domain [6-8].

An indispensable prerequisite to evaluate ACT in clinical trials is a standardized, reliable, reproducible, sterile and efficient selection of specific cell subpopulations. Moreover, the ACT approach should be scalable and follow good manufacturing practice (GMP) guidelines.

\section{Adoptive Cell Transfer in the Setting of Allogeneic Hematopoietic Progenitor Transplantation}

Adoptive T-cell therapy after HPCT, a form of ACT itself, is used for decreasing graft-versus-host disease (GvHD), enhancing antitumor immunity and promoting immune reconstitution. ACT is of therapeutic relevance in case of minimal residual disease, relapse and infectious complications and is used prophylactically in case of reduced-intensified conditioning (RIC), T-cell depleted transplantation and mixed chimerism (fig. 1). To create optimal conditions for ACT, there has to be a combination with lymphodepletion to eliminate regulatory elements and increase access to activating cytokines $[9,10]$. Several cell populations are currently considered for adoptive immunotherapy, e.g., CTLs, CD4+ helper T (Th) cells, alloreactive natural killer (NK) cells and CD4+ CD25+ regulatory $\mathrm{T}$ cells (Tregs). In the following sections, the different approaches are described.

Fig. 1. Adoptive cell transfer (ACT) after allogeneic hematopoietic progenitor cell transplantation (HPCT).

A For a lot of hematological malignancies, HPCT following myeloablative or reducedintensity conditioning (RIC) still is the only curative therapeutic option. Bone marrow (BM) or mobilized peripheral blood stem cells (PBSC) from a matched sibling donor (MSD) are the first choices in HPCT. Unfortunately, not for every patient, a MSD is available and thus, alternative sources of HPC come into play: BM or PBSC from a matched unrelated donor (MUD) or a partially mismatched related donor (haploidentical) and umbilical cord blood (UCB). B This section highlights the indication for adoptive cell therapy (ACT) and donor lymphocyte infusion (DLI). In case of RIC, a T-cell depleted transplant or mixed chimerism, ACT/DLI are prophylactically given to the patient. Therapeutically appli-

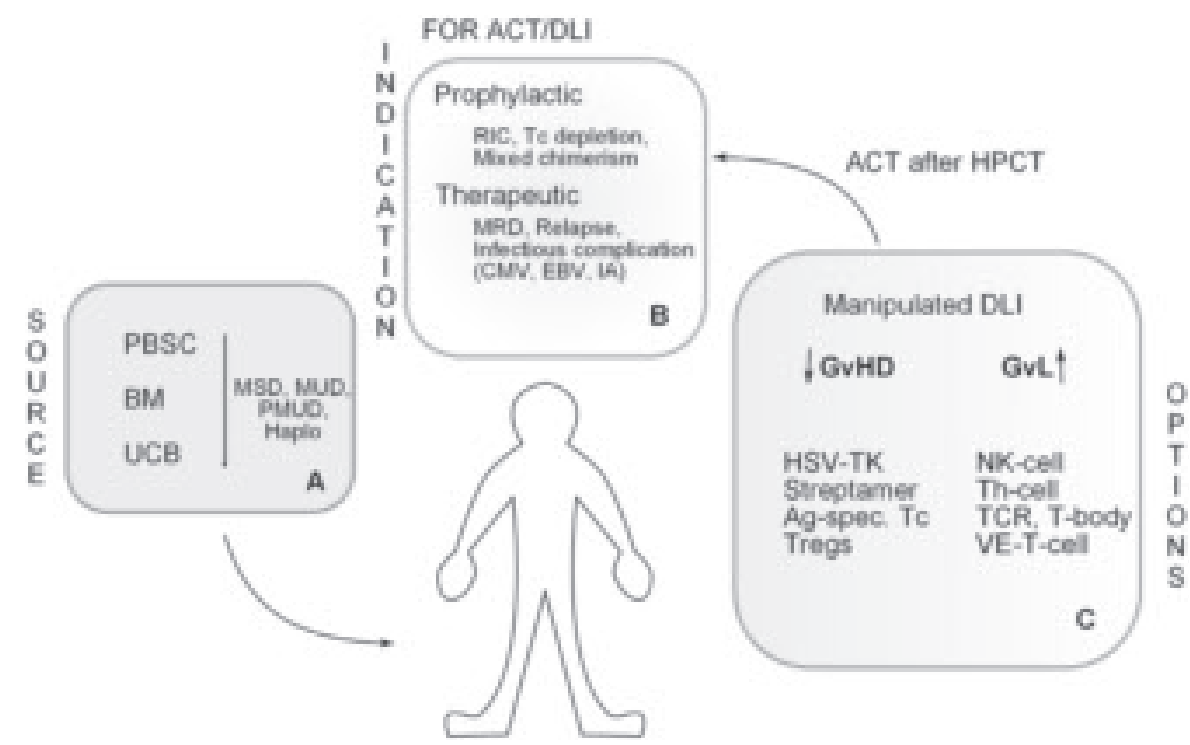
cated ACT/DLI are indicated in case of minimal residual disease (MRD), leukemic relapse or infectious complications like cytomegalovirus (CMV), Epstein-Barr-Virus (EBV) infection or invasive aspergillosis (IA). C On the one hand, DLI brings the graft-versus-leukemia effect (GvL) and on the other hand it causes graft-versus-host-disease (GvHD). The challenge is to manipulate DLI or use specific cell populations to enhance GvL (GvL $\uparrow$ ) while reducing GvHD (GvHD $\downarrow$ ). New strategies to achieve these two aims are currently developed: Lymphocytes are genetically engineered, e.g., with the herpes-simplex-virus thymidin-kinase (HSV-TK), antigen-specific lymphocytes are selected by streptamer isolation (Streptamer), Tregs, NK cells and T helper (Th) cells as well as T cells engineered to express antigen-specific T-cell receptors (TCR) or 'T bodies' are used. Another approach is the application of $\mathrm{T}$ cells parallel to a vaccine, so-called vaccine-enhanced (VE) T cells. 
The Sources of Hematopoietic Progenitor Cell Transplantation

The ideal donor for HPCT still is a matched related donor. Unfortunately, only approximately $30 \%$ of all patients have an HLA-identical sibling donor. A matched unrelated donor as the first alternative is identified in only $10 \%$ in poorly represented ethnical groups and in approximately $60 \%$ in Caucasians [11]. If there is no matched donor available, haploidentical and umbilical cord blood (UCB) transplantation come into play. A great advantage of a haploidentical transplant is that the donor is immediately available even for a second graft in the case of graft rejection. But due to HLA differences the risk of developing fatal GvHD is very high. To overcome this risk, there are several strategies to reduce the T-cell load in the graft. One possibility is an intensified conditioning regimen with fludarabin, thiotepa and total body irradiation, followed by infusion of G-CSF-stimulated peripheral blood CD34+ selected cells and combined with in vivo T-cell depletion using ATG $[12,13]$. An alternative is CD3+/CD19+ cell depletion within G-CSF-mobilized peripheral blood cells to gain a graft with large numbers of CD34+ cells, CD34- cells, CD8+ cells and NK cells [15]. This protocol is combined with RIC and subsequent immunosuppression. The main problem of these regimen is the delayed T-cell reconstitution with consecutive serious infectious problems such as CMV reactivation or invasive aspergillosis $[14,15]$.

UCB collected from the umbilical cord and placenta of a healthy newborn is another source if no matched related or unrelated donor is available. Due to the cell number needed for adults, a single UCB unit is not sufficient. Thus, the use of a transplantation of usually two UCB units [16] as well as in vitro expansion of CD34+ cells from UCB are under investigation [17]. Interestingly, GvHD in patients with UCB transplantation is decreased, and relapse rates are comparable to peripheral blood stem cell or bone marrow transplantation [18]. But infections are more frequent and more severe in the early posttransplant phase by day 100 after UCB transplantation [19]. This fact originates in the cell features of UCB cells: UCB $\mathrm{T}$ cells are naive and not antigen-experienced, show less proliferation and INF- $\gamma$ production in response to cognate antigens and have deficits in signal transduction mechanisms [20]. A further observation is that Tregs from UCB have more potent suppressor functions than adult Tregs [23]. Due to its cell characteristics, UCB is not only a source for HPCT but also a cell source for Tregs and NK cells [21] for ACT.

\section{The Role of Donor Lymphocyte Infusion in Allogeneic} Hematopoietic Progenitor Cell Transplantation

Infusion of donor lymphocytes (DLI) several weeks after HPCT (also called 'delayed' DLI) already plays a key role in supporting the graft-versus-tumor effect after allogeneic HPCT although the potency of DLI differs for each disease entitiy [22-24]. The graft-versus-leukemia (GvL) effect ob- served after allogeneic HPCT and DLI is based on the CTLmediated immunity which is reactive against minor histocompatibility antigens (mHAgs) as well as tumor/leukemia-associated antigens (TAA/LAAs) [25-27]. Minimal residual disease markers like BCR-ABL in chronic myelogenous leukemia (CML), and the proposed marker JAK2 in BCR-ABL-negative myeloproliferative neoplasms, are negative in patients in complete remission - underlining the role of T-cell-mediated immunity in the treatment $[28,29]$. These immunological effects demonstrate the potential of donor lymphocytes to reject malignant cells and suggest that LAAs are recognized by these donor lymphocytes.

\section{Reduced Intensity Conditioning and Prophylactic Donor Lymphocyte Infusion}

However, during the past decade several aspects in the conditioning regimen changed to pave the way for application of HPCT to a broader range of patients. RIC was introduced with a consequentially reduced toxicity, but GvHD-associated morbidity and mortality remained [30]. Efforts have been made to reduce GvHD-associated morbidity and mortality by in vivo T-cell depletion but this happened on the expense of impaired immune reconstitution which implicates an increased incidence of opportunistic infections and a reduced GvL effect $[33,34]$. A retrospective study of the International Bone Marrow Transplant Registry (IBMTR), described an increased leukemia relapse rate when the stem cell transplant was T-cell depleted, underlying the importance of $\mathrm{T}$ cells as effector cells in GvL [31]. Subsequently, prophylactic and dose-escalated DLI was integrated in RIC protocols to reinforce the GvL effect and prevent disease relapse but the risk of inducing GvHD remains [32].

Up to now, HPCT remains a balancing act between GvL and GvHD. Therefore, new strategies to improve early immune reconstitution and to potentiate GvL without reinforcing GvHD are needed. The following sections are going to describe the use of adoptive immunotherapy as an instrument to achieve these two aims.

\section{Adoptive T-Cell Transfer in Viral Reactivation and Fungal Infection}

After HPCT the phase of immune reconstitution represents the vulnerable phase for viral and fungal infections. Reactivation of latent viruses like cytomegalovirus (CMV), Epstein-Barr virus (EBV), herpes simplex virus (HSV) and varicella zoster virus (VZV) is frequent in this period and leads to a symptomatic disease in many cases. For example, up to $80 \%$ of CMV-seropositive allogeneic HPCT recipients develop CMV reactivation, $50 \%$ with viremia, and $40 \%$ develop active disease with pneumonia, gastroenteritis, hepatitis or retinitis [16, 37]. The antiviral drugs available are ganciclovir, foscarnet or cidofovir; however, the setback is 
that they are costly and potentially cause severe side effects and that some patients even show a chemorefractory viral disease [33]. Therefore, other strategies are needed to accelerate immune reconstitution. Non-manipulated DLI may contain virus-specific $\mathrm{T}$ cells acting against latent viruses such as CMV with average values of $0.75 \%$ and $1.85 \%$ for HLA*A0201- and HLA*B702-restricted pp65 peptides with a range from $0.13 \%$ up to $5 \%$ from all CD8+ T cells [34]. The frequency of EBV-specific CTLs in healthy virus carriers is about $1-5 \%$ from all CTLs [35]. Several groups could demonstrate a clinically relevant reconstitution of the immune system [36, 37].

Analogously to viral infections and despite prophylactic and preemptive antifungal therapy, a further major cause of morbidity and mortality of patients after HPCT is invasive aspergillosis caused by Aspergillus fumigatus [15]. Similarly to viral reactivation, invasive aspergillosis occurs in the phase of immune reconstitution; interestingly, it was reported that patients surviving aspergillosis showed significant antigenspecific proliferation of INF- $\gamma$ producing Th cells [38].

However, non-manipulated DLI contains a serious number of alloreactive $\mathrm{T}$ cells which was related to a significantly increased risk of GvHD. To provide early immune reconstitution and to reduce the risk of GvHD, CTLs specific for viral antigens such as EBV or CMV are successfully transferred to patients with active viral disease [37, 39, 40]. Not only for treatment but also for prophylaxis of EBV-associated posttransplant lymphoproliferative disease, donor-derived polyclonal EBV-specific T-cell lines were successfully applied to the patients [40, 41]. Recently, a method for rapid clinicalscale generation of human anti-Aspergillus-specific T cells was developed [42].

\section{Controlling Graft-versus-Host Disease}

\section{Suicide Gene Transfected Donor T Cells}

One approach to minimize the risk of GvHD induced by DLI is the transfection of $\mathrm{T}$ cells with a so-called suicide gene. In patients with GvHD, this gene can be activated by the administration of a drug, and as a result the transfected $\mathrm{T}$ cells are eliminated. The suicide gene most commonly applied is the thymidine kinase of herpes simplex virus (HSV-TK) which is sensitive to ganciclovir. In addition, the infusion of those genetically engineered donor lymphocytes promotes early immune reconstitution [43, 44]. One limitation of this method is that transferred cells are eliminated if early viral infection prior to HSV-TK T-cell engraftment takes place and therapy with ganciclovir is needed. Another problem is that HSV-TK represents a foreign antigen, and the transfected cells will be eliminated consequently through CTLs recognizing this particular antigen. Therefore, a second generation of suicide genes like inducible caspase 9 has been developed for adoptive T-cell therapies [45].

\section{Specific Antigen-Specific T Cells}

Another concept to avoid GvHD is isolating specific CTLs by several multimer techniques - using tetramers, pentamers [46] or streptamers [47]. CMV-specific CTLs isolated by streptamer technology are shown to have a preserved function. Currently a clinical phase I/II trial is ongoing, testing the adoptive immunotherapy of chemorefractory CMV infections with streptamer-selected T cells after HPCT. Schmitt et al. [48] reported about 2 patients in whom adoptive transfer of streptamer-selected CMV-specific CTLs lead to virus clearance after allogeneic HPCT.

It is described that long-standing responses to viral infections depend on the presence of Th cells to help CTLs [49]. Feuchtinger et al. [50] reported about the isolation of antigenspecific CD4+ and CD8+ T cells from blood of CMV seropositive donors based on the pp65-specific IFN- $\gamma$ secretion of $\mathrm{T}$ cells after ex vivo stimulation with the viral antigen. This method proved to be safe, feasible and effective as a treatment on demand for refractory CMV infection post HPCT.

\section{Regulatory T Cells}

CD4+ CD25+ Tregs, another population of interest in preventing GvHD, are central actors in maintaining self-tolerance and circumventing autoimmunity [51]. Technically, Treg separation with the help of antibody-coated magnetic beads followed by ex vivo expansion is a time-consuming and costly challenge and has to follow GMP standards to be evaluated in clinical trials. But there is a lot of promising data focusing on this cell population. Taylor et al. [52] first demonstrated in the mouse model that depletion of CD4+ CD25+ T cells from the donor T-cell population or in vivo CD25+ depletion of the recipient resulted in increased GvHD which could be ameliorated by infusion of ex vivo activated and expanded donor CD4+ CD25+ cells [52]. Freshly isolated Tregs were also able to partially suppress GvHD [52-54] with the limitation that they are only found in a low frequency in peripheral blood and there is a large number needed for suppressing GvHD. Therefore ex vivo expansion seems to be needed. Interestingly, with transfer of Tregs, GvL was preserved while GvHD was suppressed $[55,56]$. Importantly, Tregs should be administered early after HPCT because there are no data about reversing well-established GvHD [57]. Godfrey et al. [58] used UCB as the source for Tregs because in UCB there is a lack of memory $\mathrm{T}$ cells. Tregs were isolated by magnetic cell sorting, activated with anti-CD3/CD28 beads and then cultivated with IL-2. Those cells were able to suppress more than $95 \%$ of allogeneic mixed lymphocyte reactions (29 of 30 donors) [58]. Some clinical trials are underway to examine the adoptive transfer of donor Tregs to prevent GvHD. The side effects and the optimal dose of donor Tregs are tested in an ongoing phase I clinical trial called 'T-Regulatory Cell Infusion post Umbilical Cord Blood Transplant in Patients with Advanced Hematologic Cancer' (ClinicalTrials.gov Identifier: NCT00602693). In another phase I trial, headed by M. Ed- 
inger, patients with high disease relapse risk or minimal residual disease after HPCT who would preemptively receive DLI after cessation of immunosuppressive GvHD prophylaxis are sequentially treated with non-manipulated Tregs (between $1 \times 10^{6}$ and $5 \times 10^{6}$ cells $/ \mathrm{kg}$ body weight) that are freshly isolated from the original stem cell donor. Conventional DLI with equal T-cell numbers followed the infusion of Tregs. Ex vivo expansion is avoided in this protocol. Preliminary data demonstrated safety; no acute toxicities or complications like disease relapse, GvHD or infections were reported [59]. Nevertheless, Treg therapy might carry the risk of immunosuppression and consecutive disease relapse or tumor reoccurrence. In protocols with ex vivo expansion regimens, uncontrolled cell proliferation and eventually loss of the suppressor function of Tregs could be the result. It remains to be demonstrated whether those concerns are reasonable or not.

\section{Enhancing Graft-versus-Leukemia Effect}

\section{Engineered T Cells}

An alternative approach focuses on the selectivity of the donor cells. T cells can be engineered to express T-cell receptors (TCRs) which selectively recognize TAAs/LAAs. Xue et al. [60] demonstrated in an in vivo model that $\mathrm{T}$ cells, engineered to express the WT-1-TCR, are able to eliminate autologous leukemia progenitor cells [60]. Again, this strategy has limitations because every TCR recognizes the antigen in a MHC-restricted manner. Therefore, it can only be used in patients with the required MHC allele [61]. To circumvent this restriction, $\mathrm{T}$ cells which express novel chimeric fusion proteins that link the antigen-binding domain of the B-cell receptor with the signaling component of the TCR complex - socalled ' $\mathrm{T}$ bodies' - are used. To date there are only data using these TCRs for solid tumors [62]. Another restriction is that the cultured T cells used for ACT have a limited replicative potential. To improve the situation, enforced expression of co-stimulatory molecules as well as telomerase have been used $[63,64]$.

\section{NK Cells}

In haploidentical HPCT, NK cell alloreactivity is a crucial therapeutic mechanism. For NK cell function, inhibitory as well as activating killer immunoglobulin-like receptors (KIRs) are of importance. NK cells are regulated by MHC I on target cells, they are inhibited in their function by self-MHC I molecules [65]. Autologous cells are not killed by NK cells as NK cells express receptors for self-MHC I molecules, so-called inhibitory KIRs [66, 67].

In the setting of mismatched allogeneic HPCT, NK cells are not stopped from killing due to a missing expression of self-MHC I molecules - the missing self recognition mechanism. The KIRs recognize specific HLA-C allele groups and/ or the HLABw4 group and are alloreactive against cells who do not express those alleles. Alloreactive NK cells are able to kill host-type dendritic cells (DCs) which present host alloantigens to donor T cells; thus T-cell mediated GvHD is prevented [68, 69]. Consequently, the infusion of donor NK cells, alloreactive against the recipient, blocked T-cell-mediated GvHD. The extent was so strong that mice given alloreactive NK cells as part of the conditioning regimen showed no clinical or histological evidence of GvHD even after receiving mismatched bone marrow grafts containing up to 30 times the lethal dose of T cells. Alloreactive NK cells were able to kill malignant cells in acute myelogenous leukemia (AML), CML, acute lymphoblastic leukemia (ALL), T-cell acute lymphoblastic leukemia (T-ALL), chronic lymphocytic leukemia (CLL), non-Hodgkin's lymphoma (NHL) and multiple myeloma, but not in common ALL [70, 71]. Resistance was associated with lack of leukocyte function-associated antigen-1 (LFA-1) expression. In a preclinical model, transfer of alloreactive NK cells into nonobese diabetic/severe combined immunodeficiency (NOD/SCID) mice showed no clinical or histological evidence of GvHD, and mice eradicated transplanted human AML [68]. The role of NK cells in mismatched unrelated HPCT is not so clear, but recent studies show a delayed and poor reconstitution of NK cells due to the high amount of immunosuppressive drugs in this context [72]. Interestingly NK cells can be used in different settings. A study in relapsing AML patients demonstrated that NK cells harvested from haploidentical donors and infused after lymphoablating chemotherapy in the non-HPCT setting is safe and transient in vivo expansion could be detected [73]. The NKAML pilot trial [74] demonstrated the feasibility and safety of immunosuppresion with cyclophosphamide and fludarabine, followed by the infusion of donor-recipient inhibitory KIR-HLA-mismatched NK cells in 10 patients with AML as a consolidation therapy after completed chemotherapy. Contamination with $\mathrm{B}$ or $\mathrm{T}$ cells was minimal in this study and engraftment was detected in all patients. All patients remained in complete remission after a follow-up of approximately 32 months [74]. Another possibility shown by several groups is blocking the NK cell inhibitory receptors in the autologous setting. This strategy is currently tested in a phase I clinical trial with a fully human monoclonal antibody (1-7F9) in elderly patients with AML [75]. This antibody recognizes KIR2D inhibitory receptors and blocks the interaction with HLA-C molecules leading to NK cell-mediated lysis of leukemic cells. Interestingly, self-tolerance, NK cell education and function were not interfered and NK cell killing with consecutive tumor eradication was shown in preclinical murine models [76, 77]. Another possible mechanism triggered by NK cells is a polarization of the Th response towards Th2 cells [78].

\section{The Potential Role of CD4+ Th Cells}

A wide field in tumor immunology concentrates on tumorspecific CTLs which are able to directly lyse tumor cells. But 
with growing knowledge, Th cells are becoming increasingly important in their role in orchestrating an antitumor response. Th cells are providing additional stimuli to CTLs [79]. Furthermore, Th cells have the advantageous ability to recognize antigens that are presented by HLA-II molecules. These HLA-II molecules are only expressed on antigen-presenting cells, and these cells in turn close the gap between Th and CTL co-stimulation. Interestingly, HLA-II molecules can be up-regulated in tumor cells with the help of INF- $\gamma$; then they have a cytotoxic effect themselves [80]. But the experience with Th cells in adoptive cell therapy is very limited. It is more difficult to expand those cells in vitro, and due to the different Th subgroups (Th1, Th2, Th17, Treg) their phenotype is dramatically influenced by culture conditions [81]. Kim et al. [82] tested the potential role of adoptively transferred allogeneic WT1-specific CD4+ and CD8+ T lymphocytes for a sustained remission of refractory AML. A case of a 48-year-old man with myelodysplastic syndrome (RAEB-2) that progressed to AML shortly after primary diagnosis was reported. After HPCT from an HLA-matched sibling and after conditioning with fludarabine and busulfan, no GvHD occurred, but relapse appeared 10 months post transplantation. As salvage chemotherapy (FLAGIda) and repeated DLI with stem cell support resulted in complete remission of the AML and leukemic blasts showed WT1 expression, an immunotherapy with allogeneic WT1-CTLs was performed. WT1-CTLs were generated in vitro by co-cultivation of immature DCs infected with recombinant adenovirus encoding truncated WT1 and donor lymphocytes. The proportion of CD4+ and CD8+ cells was $30 \%$ and $66 \%$, respectively. Four doses of WT1-CTLs were administered after DLI and CD34 cell therapy, and the patient remained free of leukemia for 37 months after immunotherapy until relapse [82]. In conclusion, in orchestrating a sufficient antitumor immune response, Th cells seem to play a key role. Thus, the concept of successful adoptive immunotherapy would be a combination of antigen-specific Th cells with CTL cells.

To date, the majority of stem cell transplants for hematopoietic transplantation is mobilized by G-CSF, which means a 10 times increased number of $\mathrm{T}$ cells infused compared to an equivalent bone marrow graft. In a meta-analysis, a decreased relapse rate and an increased GvL effect was reported for patients with early- and advanced-stage disease as well as a significant risk for the development of chronic GvHD [83]. Interestingly, acute GvHD is described as a Th1 (secreting IL-2 and INF- $\gamma$ )-mediated disease with induction of a cytokine storm, whereas chronic GvHD seems to equal in part an autoimmune disease $[84,85]$. Th2 cells (secreting IL-4 and IL-10) seem to suppress inflammatory processes and reduce acute GvHD. The risk of acute GvHD decreases possibly due to the immunomodulatory effect of G-CSF shown by several groups. G-CSF mobilization leads to a polarization of Th cells towards the Th2 cell pool, therefore elevated levels of type 2 cytokines (IL-4 and IL-10) and decreased levels of the type 1 cytokines IL-2, IL-12 and INF- $\gamma$ upon alloantigen stimulation were reported [86-88]. However, in a recent study, Hill et al. [89] postulated that G-CSF rather invokes Th17 induction than Th1 or Th2 differentiation [89]. To summarize, a lot of data indicates that G-CSF promotes an immune tolerant state in T cells by inducing a shift towards Th2 and even Tregs [90], apart from the pro-inflammatory subset Th1 while the effect of G-CSF on Th17 cells is controversially discussed.

\section{Vaccine-Enhanced T Cells}

A novel approach to improve immune function and link the two aims - enhancing GvL and suppressing GvHD - following HPCT, is vaccination-enhanced DLI which serves as an in vivo expansion of specific T cells [91]. A key advantage of this method would be that no labor- or cost-intensive in vitro expansion of specific $\mathrm{T}$ cells would be needed and at the same time two clinically approved techniques could be combined: DLI plus vaccination (peptides, DCs). This concept was tested recently by Levenga et al. [92] in patients with multiple myeloma receiving a combination of DLI and DC vaccination after HPCT [92]. Analogously, it could become a concept to treat patients with CMV reactivation after HPCT to combine CMV-peptide vaccination with DLI [93].

\section{Leukemia-Associated Antigens as Target Structures for T-Cell Therapy after HPCT}

To improve the effects of immunotherapy, it is important to develop more leukemia-specific T-cell therapies. The antitumor effect of an adoptive T-cell immunotherapy critically depends on the selection of the target antigen. First, the ideal antigen would be highly immunogenic to elicit a specific T-cell response. Second, it would be selectively expressed by leukemic cells and ideally not by normal tissue, thus preventing GvHD. Third, it should be expressed or at least be presented on the surface of the cells. Fourth, it should play a key role in proliferation and survival of the leukemic cells so that targeting the antigen would lead to apoptosis of the malignant cells.

On the one hand, mHags such as HA-1, HA-2, PANE-1 and LRH-1 are suitable antigens [94-96]. A clinical phase I study previously tested the CTL transfer specific for mHags with the potential risk of inducing severe GvHD [97]. This study underlines the importance of selecting the ideal tissuerestricted antigen.

On the other hand, LAAs are defined, and candidates like WT1, PR3, hTERT, Survivin, PRAME and RHAMM are available [98]. The frequency of LAA-specific CTLs is often very low. Hence, efforts are made to expand LAA-specific $\mathrm{T}$ cells in vitro for ACT in vivo with the help of peptide vaccination. For example, Quintarelli et al. [99] generated HLAA02-restricted PRAME-specific CTL responses, demonstrating the possible role of this LAA for peptide vaccination by means of in vivo expansion of CTLs in CML. Interestingly, 
PRAME-specific CTLs isolated from healthy donors showed higher avidity than CTLs from CML patients [99].

The application of some LAAs after HPCT is tested in various studies. A phase I trial with the bivalent peptide vaccination of PR1 and WT1 demonstrated immunological but also clinical responses of patients after allogeneic HPCT [100]. A phase I/II trial for patients with AML, myelodysplastic syndrome and multiple myeloma was performed for RHAMM likewise with the detection of clinical and immunological responses [101, 102].

For the future, the combination of peptide or DC vaccination with DLI (vaccine-enhanced DLI) would be a promising concept to enhance GvL and suppress GvHD but further studies have to confirm their relevance in vivo.

\section{Conclusion}

To date, HPCT is a promising treatment option in several hematological malignancies. However, delayed immune reconstitution with viral reactivation, development of GvHD and disease relapse still represent risks that cannot be sufficiently controlled in every patient. Therefore, the ambitious aim of adoptive immunotherapy is to enhance GvL and im- mune reconstitution and suppress GvHD. DLI as the prototype of ACT demonstrated the potential of immunotherapy after allogeneic HPCT. Plenty of cell populations like CTLs, Th cells, Tregs and NK cells are under investigation, and a lot of clinical trials have to be performed to identify their clinical relevance. In addition, peptide and DC vaccination concepts with LAAs as target structures are under clinical investigation.

Nevertheless, the future of ACT may lie in combining several strategies like pretreatment with lymphodepleting chemotherapy and adoptive T-cell transplantation with vaccination to increase the tumor-reactive T-cell population in vivo.

\section{Acknowledgements}

This work was supported by a generous grant from the German José Carreras Leukemia Foundation to J.G. and L.B. (DJCLS A 10/01, R07/15v and R09/13) and the German Research Foundation (DFG GR2676/3-1). Thanks to Marlies Götz for critically reading the manuscript.

\section{Disclosure Statement}

The authors declare no competing financial interests.

\section{References}

1 Mackensen A, Meidenbauer N, Vogl S, Laumer M, Berger J, Andreesen R: Phase I study of adoptive T-cell therapy using antigen-specific CD8+ T cells for the treatment of patients with metastatic melanoma. J Clin Oncol 2006;24:5060-5069.

$\checkmark 2$ Yee C, Thompson JA, Byrd D, Riddell SR, Roche P, Celis E, Greenberg PD: Adoptive T cell therapy using antigen-specific CD8+ T cell clones for the treatment of patients with metastatic melanoma: in vivo persistence, migration, and antitumor effect of transferred T cells. Proc Natl Acad Sci U S A 2002; 99:16168-16173.

3 Dudley ME, Wunderlich JR, Yang JC, Sherry RM, Topalian SL, Restifo NP, Royal RE, Kammula U, White DE, Mavroukakis SA, Rogers LJ, Gracia GJ, Jones SA, Mangiameli DP, Pelletier MM, Gea-Banacloche J, Robinson MR, Berman DM, Filie AC, Abati A, Rosenberg SA: Adoptive cell transfer therapy following non-myeloablative but lymphodepleting chemotherapy for the treatment of patients with refractory metastatic melanoma. J Clin Oncol 2005;23:2346-2357.

4 Markel G, Cohen-Sinai T, Besser MJ, Oved K, Itzhaki O, Seidman R, Fridman E, Treves AJ, Keisari Y, Dotan Z, Ramon J, Schachter J: Preclinical evaluation of adoptive cell therapy for patients with metastatic renal cell carcinoma. Anticancer Res 2009;29:145-154.

5 Dudley ME, Wunderlich JR, Shelton TE, Even J, Rosenberg SA: Generation of tumor-infiltrating lymphocyte cultures for use in adoptive transfer therapy for melanoma patients. J Immunother 2003; 26:332-342.
6 Eshhar Z, Waks T, Bendavid A, Schindler DG: Functional expression of chimeric receptor genes in human T cells. J Immunol Methods 2001;248: $67-76$.

7 Johnson LA, Morgan RA, Dudley ME, Cassard L, Yang JC, Hughes MS, Kammula US, Royal RE, Sherry RM, Wunderlich JR, Lee CC, Restifo NP, Schwarz SL, Cogdill AP, Bishop RJ, Kim H, Brewer CC, Rudy SF, VanWaes C, Davis JL, Mathur A, Ripley RT, Nathan DA, Laurencot CM, Rosenberg SA: Gene therapy with human and mouse $\mathrm{T}$-cell receptors mediates cancer regression and targets normal tissues expressing cognate antigen. Blood 2009;114:535-546.

8 Rosenberg SA, Yang JC, Robbins PF, Wunderlich JR, Hwu P, Sherry RM, Schwartzentruber DJ, Topalian SL, Restifo NP, Filie A, Chang R, Dudley ME: Cell transfer therapy for cancer: lessons from sequential treatments of a patient with metastatic melanoma. J Immunother 2003;26:385-393.

9 Wrzesinski C, Restifo NP: Less is more: lymphodepletion followed by hematopoietic stem cell transplant augments adoptive T-cell-based anti-tumor immunotherapy. Curr Opin Immunol 2005;17:195201.

10 Wrzesinski C, Paulos CM, Kaiser A, Muranski P, Palmer DC, Gattinoni L, Yu Z, Rosenberg SA, Restifo NP: Increased intensity lymphodepletion enhances tumor treatment efficacy of adoptively transferred tumor-specific T cells. J Immunother 2010;33:1-7.

11 Hansen JA, Petersdorf E, Martin PJ, Anasetti C: Hematopoietic stem cell transplants from unrelated donors. Immunol Rev 1997;157:141-151.
12 Aversa F, Tabilio A, Velardi A, Cunningham I, Terenzi A, Falzetti F, Ruggeri L, Barbabietola G, Aristei C, Latini P, Reisner Y, Martelli MF: Treatment of high-risk acute leukemia with T-celldepleted stem cells from related donors with one fully mismatched HLA haplotype. N Engl J Med 1998;339:1186-1193.

13 Reisner Y, Martelli MF: Tolerance induction by 'megadose' transplants of CD34+ stem cells: A new option for leukemia patients without an HLAmatched donor. Curr Opin Immunol 2000;12:536541.

14 Boeckh M, Nichols WG, Papanicolaou G, Rubin $\mathrm{R}$, Wingard JR, Zaia J: Cytomegalovirus in hematopoietic stem cell transplant recipients: current status, known challenges, and future strategies. Biol Blood Marrow Transplant 2003;9:543-558.

15 Marr KA, Carter RA, Boeckh M, Martin P, Corey L: Invasive aspergillosis in allogeneic stem cell transplant recipients: changes in epidemiology and risk factors. Blood 2002;100:4358-4366.

16 Barker JN, Weisdorf DJ, DeFor TE, Blazar BR, McGlave PB, Miller JS, Verfaillie CM, Wagner JE: Transplantation of 2 partially HLA-matched umbilical cord blood units to enhance engraftment in adults with hematologic malignancy. Blood 2005; 105:1343-1347.

17 Delaney C, Heimfeld S, Brashem-Stein C, Voorhies H, Manger RL, Bernstein ID: Notchmediated expansion of human cord blood progenitor cells capable of rapid myeloid reconstitution. Nat Med 2010;16:232-236. 
18 Rocha V, Labopin M, Sanz G, Arcese W, Schwerdtfeger R, Bosi A, Jacobsen N, Ruutu T, de Lima M, Finke J, Frassoni F, Gluckman E: Transplants of umbilical-cord blood or bone marrow from unrelated donors in adults with acute leukemia. $\mathrm{N}$ Engl J Med 2004;351:2276-2285.

19 Escalon MP, Champlin RE, Saliba RM, Acholonu SA, Hosing C, Fayad L, Giralt S, Ueno NT, Maadani F, Pro B, Donato M, McLaughlin P, Khouri IF: Nonmyeloablative allogeneic hematopoietic transplantation: a promising salvage therapy for patients with non-Hodgkin's lymphoma whose disease has failed a prior autologous transplantation. J Clin Oncol 2004;22:2419-2423.

20 Komanduri KV, St John LS, de Lima M, McMannis J, Rosinski S, McNiece I, Bryan SG, Kaur I, Martin S, Wieder ED, Worth L, Cooper LJ, Petropoulos D, Molldrem JJ, Champlin RE, Shpall EJ Delayed immune reconstitution after cord blood transplantation is characterized by impaired thymopoiesis and late memory T-cell skewing. Blood 2007;110:4543-4551.

21 Verneris MR, Miller JS: The phenotypic and functional characteristics of umbilical cord blood and peripheral blood natural killer cells. Br J Haematol 2009;147:185-191.

22 Bloor AJ, Thomson K, Chowdhry N, Verfuerth S, Ings SJ, Chakraverty R, Linch DC, Goldstone AH, Peggs KS, Mackinnon S: High response rate to donor lymphocyte infusion after allogeneic stem cell transplantation for indolent non-Hodgkin lymphoma. Biol Blood Marrow Transplant 2008; 14:50-58.

23 Kolb HJ, Schattenberg A, Goldman JM, Hertenstein B, Jacobsen N, Arcese W, Ljungman P, Ferrant A, Verdonck L, Niederwieser D, van Rhee F, Mittermueller J, de Witte T, Holler E, Ansari H: Graft-versus-leukemia effect of donor lymphocyte transfusions in marrow grafted patients. Blood 1995;86:2041-2050.

24 Schmid C, Labopin M, Nagler A, Bornhauser M, Finke J, Fassas A, Volin L, Gurman G, Maertens J, Bordigoni P, Holler E, Ehninger G, Polge E, Gorin NC, Kolb HJ, Rocha V: Donor lymphocyte infusion in the treatment of first hematological relapse after allogeneic stem-cell transplantation in adults with acute myeloid leukemia: a retrospective risk factors analysis and comparison with other strategies by the EBMT Acute Leukemia Working Party. J Clin Oncol 2007;25:4938-4945.

25 Apperley JF, Mauro FR, Goldman JM, Gregory W, Arthur CK, Hows J, Arcese W, Papa G, Mandelli F, Wardle D, et al: Bone marrow transplantation for chronic myeloid leukaemia in first chronic phase: importance of a graft-versus-leukaemia effect. Br J Haematol 1988;69:239-245.

26 Falkenburg JH, van de Corput L, Marijt EW, Willemze R: Minor histocompatibility antigens in human stem cell transplantation. Exp Hematol 2003;31:743-751.

27 Goulmy E: Human minor histocompatibility antigens: new concepts for marrow transplantation and adoptive immunotherapy. Immunol Rev 1997;157:125-140.

-28 Kroger N, Badbaran A, Holler E, Hahn J, Kobbe G, Bornhauser M, Reiter A, Zabelina T, Zander AR, Fehse B: Monitoring of the JAK2-V617F mutation by highly sensitive quantitative real-time PCR after allogeneic stem cell transplantation in patients with myelofibrosis. Blood 2007;109:13161321
29 Sadovnikova E, Stauss HJ: Peptide-specific cytotoxic $\mathrm{T}$ lymphocytes restricted by nonself major histocompatibility complex class I molecules: reagents for tumor immunotherapy. Proc Natl Acad Sci U S A 1996;93:13114-13118.

30 Mielcarek M, Martin PJ, Leisenring W, Flowers ME, Maloney DG, Sandmaier BM, Maris MB, Storb R: Graft-versus-host disease after nonmyeloablative versus conventional hematopoietic stem cell transplantation. Blood 2003;102:756-762.

31 Horowitz MM, Gale RP, Sondel PM, Goldman JM, Kersey J, Kolb HJ, Rimm AA, Ringden O, Rozman C, Speck B, et al: Graft-versus-leukemia reactions after bone marrow transplantation. Blood 1990;75:555-562.

32 Peggs KS, Thomson K, Hart DP, Geary J, Morris EC, Yong K, Goldstone AH, Linch DC, Mackinnon S: Dose-escalated donor lymphocyte infusions following reduced intensity transplantation: toxicity, chimerism, and disease responses. Blood 2004;103:1548-1556.

33 Ljungman P, Brand R, Einsele H, Frassoni F, Niederwieser D, Cordonnier C: Donor CMV serologic status and outcome of CMV-seropositive recipients after unrelated donor stem cell transplantation: an EBMT megafile analysis. Blood 2003;102:42554260.

34 Gillespie GM, Wills MR, Appay V, O'Callaghan C, Murphy M, Smith N, Sissons P, Rowland-Jones S, Bell JI, Moss PA: Functional heterogeneity and high frequencies of cytomegalovirus-specific CD8(+) T lymphocytes in healthy seropositive donors. J Virol 2000;74:8140-8150.

35 Tan LC, Gudgeon N, Annels NE, Hansasuta P, O'Callaghan CA, Rowland-Jones S, McMichael AJ, Rickinson AB, Callan MF: A re-evaluation of the frequency of CD8+ T cells specific for EBV in healthy virus carriers. J Immunol 1999;162:18271835.

36 Hromas R, Cornetta K, Srour E, Blanke C, Broun ER: Donor leukocyte infusion as therapy of lifethreatening adenoviral infections after T-celldepleted bone marrow transplantation. Blood 1994;84:1689-1690.

37 Papadopoulos EB, Ladanyi M, Emanuel D, Mackinnon S, Boulad F, Carabasi MH, CastroMalaspina H, Childs BH, Gillio AP, Small TN, et al: Infusions of donor leukocytes to treat EpsteinBarr virus-associated lymphoproliferative disorders after allogeneic bone marrow transplantation. N Engl J Med 1994;330:1185-1191.

38 Hebart H, Bollinger C, Fisch P, Sarfati J, Meisner C, Baur M, Loeffler J, Monod M, Latge JP, Einsele H: Analysis of T-cell responses to Aspergillus fumigatus antigens in healthy individuals and patients with hematologic malignancies. Blood 2002;100:4521-4528.

39 Riddell SR, Watanabe KS, Goodrich JM, Li CR, Agha ME, Greenberg PD: Restoration of viral immunity in immunodeficient humans by the adoptive transfer of T cell clones. Science 1992;257: 238-241.

40 Rooney CM, Smith CA, Ng CY, Loftin SK, Sixbey JW, Gan Y, Srivastava DK, Bowman LC, Krance RA, Brenner MK, Heslop HE: Infusion of cytotoxic $\mathrm{T}$ cells for the prevention and treatment of Epstein-Barr virus-induced lymphoma in allogeneic transplant recipients. Blood 1998;92:1549-1555.

41 Heslop HE, Ng CY, Li C, Smith CA, Loftin SK, Krance RA, Brenner MK, Rooney CM: Long-term restoration of immunity against Epstein-Barr virus infection by adoptive transfer of gene-modified virus-specific T lymphocytes. Nat Med 1996;2:551555 .
42 Tramsen L, Koehl U, Tonn T, Latge JP, Schuster FR, Borkhardt A, Uharek L, Quaritsch R, Beck O, Seifried E, Klingebiel T, Lehrnbecher T: Clinicalscale generation of human anti-Aspergillus $\mathrm{T}$ cells for adoptive immunotherapy. Bone Marrow Transplant 2009;43:13-19.

43 Ciceri F, Bonini C, Marktel S, Zappone E, Servida P, Bernardi M, Pescarollo A, Bondanza A, Peccatori J, Rossini S, Magnani Z, Salomoni M, Benati C, Ponzoni M, Callegaro L, Corradini P, Bregni $\mathrm{M}$, Traversari C, Bordignon C: Antitumor effects of HSV-TK-engineered donor lymphocytes after allogeneic stem-cell transplantation. Blood 2007;109:4698-4707.

44 Bonini C, Ferrari G, Verzeletti S, Servida P, Zappone E, Ruggieri L, Ponzoni M, Rossini S, Mavilio F, Traversari C, Bordignon C: HSV-TK gene transfer into donor lymphocytes for control of allogeneic graft-versus-leukemia. Science 1997;276:1719_ 1724 .

45 Straathof KC, Pule MA, Yotnda P, Dotti G, Vanin EF, Brenner MK, Heslop HE, Spencer DM, Rooney CM: An inducible caspase 9 safety switch for T-cell therapy. Blood 2005;105:4247-4254.

46 Duplan V, Suberbielle E, Napper CE, Joly E, Saoudi A, Gonzalez-Dunia D: Tracking antigenspecific CD8+ T cells in the rat using MHC class I multimers. J Immunol Methods 2007;320:30-39.

47 Knabel M, Franz TJ, Schiemann M, Wulf A, Villmow B, Schmidt B, Bernhard H, Wagner H, Busch DH: Reversible MHC multimer staining for functional isolation of T-cell populations and effective adoptive transfer. Nat Med 2002;8:631-637.

48 Schmitt A, Tonn T, Busch DH, Grigoleit GU, Einsele H, Odendahl M, Germeroth L, Ringhoffer M, Ringhoffer S, Wiesneth M, Greiner J, Michel D, Mertens T, Rojewski M, Marx M, Von Harsdorf S, Dohner H, Seifried E, Bunjes D, Schmitt M: Adoptive transfer and selective reconstitution of streptamer-selected cytomegalovirus-specific CD8+ $\mathrm{T}$ cells leads to virus clearance in patients after allogeneic peripheral blood stem cell transplantation. Transfusion 2011;51:591-599.

49 Sun JC, Williams MA, Bevan MJ: CD4+ T cells are required for the maintenance, not programming, of memory CD8+ T cells after acute infection. Nat Immunol 2004;5:927-933.

50 Feuchtinger T, Opherk K, Bethge WA, Topp MS, Schuster FR, Weissinger EM, Mohty M, Or R, Maschan M, Schumm M, Hamprecht K, Handgretinger R, Lang P, Einsele H: Adoptive transfer of pp65-specific T-cells for the treatment of chemorefractory cytomegalovirus disease or reactivation after haploidentical and matched unrelated stem cell transplantation. Blood 2010;116:4360-4367.

51 Sakaguchi S, Sakaguchi N, Asano M, Itoh M, Toda $\mathrm{M}$ : Immunologic self-tolerance maintained by activated $t$ cells expressing IL-2 receptor alpha-chains (CD25). Breakdown of a single mechanism of selftolerance causes various autoimmune diseases. J Immunol 1995;155:1151-1164.

52 Taylor PA, Lees CJ, Blazar BR: The infusion of ex vivo activated and expanded CD4(+)CD25(+) immune regulatory cells inhibits graft-versus-host disease lethality. Blood 2002;99:3493-3499.

53 Cohen JL, Trenado A, Vasey D, Klatzmann D, Salomon BL: CD4(+)CD25(+) immunoregulatory T cells: new therapeutics for graft-versus-host disease. J Exp Med 2002;196:401-406.

54 Hoffmann P, Ermann J, Edinger M, Fathman CG, Strober S: Donor-type CD4(+)CD25(+) regulatory $\mathrm{T}$ cells suppress lethal acute graft-versus-host disease after allogeneic bone marrow transplantation. J Exp Med 2002;196:389-399. 
-55 Edinger M, Hoffmann P, Ermann J, Drago K, Fathman CG, Strober S, Negrin RS: CD4+CD25+ regulatory $\mathrm{T}$ cells preserve graft-versus-tumor activity while inhibiting graft-versus-host disease after bone marrow transplantation. Nat Med 2003; 9:1144-1150.

56 Trenado A, Charlotte F, Fisson S, Yagello M, Klatzmann D, Salomon BL, Cohen JL: Recipienttype specific CD4+CD25+ regulatory $\mathrm{T}$ cells favor immune reconstitution and control graft-versushost disease while maintaining graft-versus-leukemia. J Clin Invest 2003;112:1688-1696.

57 Jones SC, Murphy GF, Korngold R: Post-hematopoietic cell transplantation control of graft-versus-host disease by donor CD425 T cells to allow an effective graft-versus-leukemia response. Biol Blood Marrow Transplant 2003;9:243-256.

58 Godfrey WR, Spoden DJ, Ge YG, Baker SR, Liu B, Levine BL, June CH, Blazar BR, Porter SB: Cord blood CD4(+)CD25(+)-derived $\mathrm{T}$ regulatory cell lines express FoxP3 protein and manifest potent suppressor function. Blood 2005;105:750-758.

59 Roncarolo MG, Battaglia M: Regulatory T-cell immunotherapy for tolerance to self antigens and alloantigens in humans. Nat Rev Immunol 2007:7:585-598

-60 Xue SA, Gao L, Thomas S, Hart DP, Xue JZ, Gillmore R, Voss RH, Morris E, Stauss HJ: Development of a Wilms' tumor antigen-specific T-cell receptor for clinical trials: engineered patient's T cells can eliminate autologous leukemia blasts in NOD/SCID mice. Haematologica 2010;95:126-134.

61 Morgan RA, Dudley ME, Wunderlich JR, Hughes MS, Yang JC, Sherry RM, Royal RE, Topalian SL, Kammula US, Restifo NP, Zheng Z, Nahvi A, de Vries CR, Rogers-Freezer LJ, Mavroukakis SA, Rosenberg SA: Cancer regression in patients after transfer of genetically engineered lymphocytes. Science 2006;314:126-129.

62 Kershaw MH, Westwood JA, Parker LL, Wang G, Eshhar Z, Mavroukakis SA, White DE, Wunderlich JR, Canevari S, Rogers-Freezer L, Chen CC, Yang JC, Rosenberg SA, Hwu P: A phase I study on adoptive immunotherapy using gene-modified $\mathrm{T}$ cells for ovarian cancer. Clin Cancer Res 2006;12:6106-6115.

63 Hooijberg E, Ruizendaal JJ, Snijders PJ, Kueter EW, Walboomers JM, Spits H: Immortalization of human CD8+ T cell clones by ectopic expression of telomerase reverse transcriptase. J Immunol 2000; 165:4239-4245.

64 Topp MS, Riddell SR, Akatsuka Y, Jensen MC Blattman JN, Greenberg PD: Restoration of CD28 expression in CD28- CD8+ memory effector $\mathrm{T}$ cells reconstitutes antigen-induced IL-2 production. J Exp Med 2003;198:947-955.

65 Moretta L, Moretta A: Unravelling natural killer cell function: triggering and inhibitory human NK receptors. EMBO J 2004;23:255-259.

66 Colonna M, Brooks EG, Falco M, Ferrara GB, Strominger JL: Generation of allospecific natural killer cells by stimulation across a polymorphism of HLA-C. Science 1993;260:1121-1124.

-67 Moretta A, Bottino C, Pende D, Tripodi G, Tambussi G, Viale O, Orengo A, Barbaresi M, Merli A, Ciccone E, et al: Identification of four subsets of human CD3-CD16+ natural killer (NK) cells by the expression of clonally distributed functional surface molecules: Correlation between subset assignment of NK clones and ability to mediate specific alloantigen recognition. J Exp Med 1990; 172:1589-1598.
68 Ruggeri L, Capanni M, Urbani E, Perruccio K, Shlomchik WD, Tosti A, Posati S, Rogaia D, Frassoni F, Aversa F, Martelli MF, Velardi A: Effectiveness of donor natural killer cell alloreactivity in mismatched hematopoietic transplants. Science 2002;295:2097-2100.

69 Shlomchik WD, Couzens MS, Tang CB, McNiff J, Robert ME, Liu J, Shlomchik MJ, Emerson SG: Prevention of graft versus host disease by inactivation of host antigen-presenting cells. Science 1999;285:412-415.

70 Ruggeri L, Capanni M, Casucci M, Volpi I, Tosti A, Perruccio K, Urbani E, Negrin RS, Martelli MF, Velardi A: Role of natural killer cell alloreactivity in HLA-mismatched hematopoietic stem cell transplantation. Blood 1999:94:333-339.

71 Ruggeri L, Mancusi A, Capanni M, Urbani E, Carotti A, Aloisi T, Stern M, Pende D, Perruccio K, Burchielli E, Topini F, Bianchi E, Aversa F, Martelli MF, Velardi A: Donor natural killer cell allorecognition of missing self in haploidentical hematopoietic transplantation for acute myeloid leukemia: challenging its predictive value. Blood 2007;110:433-440.

72 Shilling HG, McQueen KL, Cheng NW, Shizuru JA, Negrin RS, Parham P: Reconstitution of NK cell receptor repertoire following HLA-matched hematopoietic cell transplantation. Blood 2003;101: 3730-3740.

73 Miller JS, Soignier Y, Panoskaltsis-Mortari A, McNearney SA, Yun GH, Fautsch SK, McKenna D, Le C, Defor TE, Burns LJ, Orchard PJ, Blazar BR, Wagner JE, Slungaard A, Weisdorf DJ, Okazaki IJ, McGlave PB: Successful adoptive transfer and in vivo expansion of human haploidentical NK cells in patients with cancer. Blood 2005;105:3051-3057.

74 Rubnitz JE, Inaba H, Ribeiro RC, Pounds S, Rooney B, Bell T, Pui CH, Leung W: NKAML: a pilot study to determine the safety and feasibility of haploidentical natural killer cell transplantation in childhood acute myeloid leukemia. J Clin Oncol 2010;28:955-959.

75 Vey N, Bourhis J, Dombret H, Bordessoule D, Prebet T, Charbonnier A, Squiban P, Damholt B, Blaise D, Olive D. A phase I study of the anti-natural killer inhibitory receptor (KIR) monoclonal antibody (1-7F9, IPH2101) in elderly patients with acute myeloid leukemia (AML). J Clin Oncol 2009;27(15 suppl), abstr 3015.

76 Romagne F, Andre P, Spee P, Zahn S, Anfossi N, Gauthier L, Capanni M, Ruggeri L, Benson DM Jr, Blaser BW, Della Chiesa M, Moretta A, Vivier E, Caligiuri MA, Velardi A, Wagtmann N: Preclinical characterization of 1-7f9, a novel human anti-KIR receptor therapeutic antibody that augments natural killer-mediated killing of tumor cells. Blood 2009;114:2667-2677.

77 Sola C, Andre P, Lemmers C, Fuseri N, Bonnafous C, Blery M, Wagtmann NR, Romagne F, Vivier E, Ugolini S: Genetic and antibody-mediated reprogramming of natural killer cell missing-self recognition in vivo. Proc Natl Acad Sci U S A 2009;106: 12879-12884.

78 Yang J, Gao L, Liu Y, Ren Y, Xie R, Fan H, Qian $\mathrm{K}$ : Adoptive therapy by transfusing expanded donor murine natural killer $\mathrm{T}$ cells can suppress acute graft-versus-host disease in allogeneic bone marrow transplantation. Transfusion 2010;50:407417.

79 Surman DR, Dudley ME, Overwijk WW, Restifo NP: Cutting edge: CD4+ T cell control of CD8+ $\mathrm{T}$ cell reactivity to a model tumor antigen. $\mathrm{J}$ Immunol 2000;164:562-565.
80 Heller KN, Gurer C, Munz C: Virus-specific CD4+ T cells: ready for direct attack. J Exp Med 2006; 203:805-808.

81 Foulds KE, Zenewicz LA, Shedlock DJ, Jiang J, Troy AE, Shen H: Cutting edge: CD4 and CD8 T cells are intrinsically different in their proliferative responses. J Immunol 2002;168:1528-1532.

82 Kim YJ, Cho SG, Lee S, Kim MS, Kim EK, Cho BS, Sohn HJ, Choi HB, Eom KS, Min CK, Kim HJ, Kim YG, Kim DW, Lee JW, Min WS, Kim CC, Kim TG: Potential role of adoptively transferred allogeneic WT1-specific CD4+ and CD8+ T lymphocytes for the sustained remission of refractory AML. Bone Marrow Transplant 2010;45:597-599.

83 Stem Cell Trialists' Collaborative Group: Allogeneic peripheral blood stem-cell compared with bone marrow transplantation in the management of hematologic malignancies: an individual patient data meta-analysis of nine randomized trials. J Clin Oncol 2005;23:5074-5087.

84 Shlomchik WD: Graft-versus-host disease. Nat Rev Immunol 2007;7:340-352

85 Hill GR, Ferrara JL: The primacy of the gastrointestinal tract as a target organ of acute graft-versus-host disease: rationale for the use of cytokine shields in allogeneic bone marrow transplantation. Blood 2000;95:2754-2759.

86 Hartung T, Docke WD, Gantner F, Krieger G, Sauer A, Stevens P, Volk HD, Wendel A: Effect of granulocyte colony-stimulating factor treatment on ex vivo blood cytokine response in human volunteers. Blood 1995;85:2482-2489.

87 Pan L, Delmonte J Jr, Jalonen CK, Ferrara JL: Pretreatment of donor mice with granulocyte colony-stimulating factor polarizes donor $\mathrm{T}$ lymphocytes toward type- 2 cytokine production and reduces severity of experimental graft-versus-host disease. Blood 1995;86:4422-4429.

88 Nawa Y, Teshima T, Sunami K, Hiramatsu Y, Yano T, Shinagawa K, Omoto E, Harada M: Responses of granulocyte colony-stimulating factormobilized peripheral blood mononuclear cells to alloantigen stimulation. Blood 1997;90:1716-1718.

89 Hill GR, Olver SD, Kuns RD, Varelias A, Raffelt NC, Don AL, Markey KA, Wilson YA, Smyth MJ, Iwakura $\mathrm{Y}$, Tocker J, Clouston $\mathrm{AD}$, Macdonald KP: Stem cell mobilization with G-CSF induces type 17 differentiation and promotes scleroderma. Blood 2010;116:819-828.

90 Zou L, Barnett B, Safah H, Larussa VF, Evdemon-Hogan M, Mottram P, Wei S, David O Curiel TJ, Zou W: Bone marrow is a reservoir for CD4+CD25+ regulatory T cells that traffic through CXCL12/CXCR4 signals. Cancer Res 2004;64: 8451-8455.

91 Roback JD: Vaccine-enhanced donor lymphocyte infusion (VEDLI). Hematology Am Soc Hematol Educ Program 2006;513:486-491.

92 Levenga H, Schaap N, Maas F, Esendam B, Fredrix H, Greupink-Draaisma A, de Witte T, Dolstra H, Raymakers R: Partial T cell-depleted allogeneic stem cell transplantation following reduced-intensity conditioning creates a platform for immunotherapy with donor lymphocyte infusion and recipient dendritic cell vaccination in multiple myeloma. Biol Blood Marrow Transplant 2010;16:320-332.

93 Schmitt A, Bechter C, Yao J, Goetz M, Maccari B, Schauwecker P, Wiesneth M, Schmitt M: Cytomegalovirus vaccination of leukemia and lymphoma patients after allogeneic stem cell transplantation - validation of a peptide vaccine. J Immunol Methods 2009;343:140-147. 
-94 Brickner AG, Evans AM, Mito JK, Xuereb SM, Feng X, Nishida T, Fairfull L, Ferrell RE, Foon KA, Hunt DF, Shabanowitz J, Engelhard VH, Riddell SR, Warren EH: The pane1 gene encodes a novel human minor histocompatibility antigen that is selectively expressed in B-lymphoid cells and B-CLL. Blood 2006;107:3779-3786.

-95 de Bueger M, Bakker A, Van Rood JJ, Van der Woude F, Goulmy E: Tissue distribution of human minor histocompatibility antigens. Ubiquitous versus restricted tissue distribution indicates heterogeneity among human cytotoxic $\mathrm{T}$ lymphocyte-defined non-MHC antigens. J Immunol 1992;149:1788-1794.

96 de Rijke B, van Horssen-Zoetbrood A, Beekman JM, Otterud B, Maas F, Woestenenk R, Kester M, Leppert M, Schattenberg AV, de Witte T, van de Wiel-van Kemenade E, Dolstra H: A frameshift polymorphism in P2X5 elicits an allogeneic cytotoxic $\mathrm{T}$ lymphocyte response associated with remission of chronic myeloid leukemia. J Clin Invest 2005;115:3506-3516

\$97 Warren EH, Fujii N, Akatsuka Y, Chaney CN, Mito JK, Loeb KR, Gooley TA, Brown ML, Koo KK, Rosinski KV, Ogawa S, Matsubara A, Appelbaum FR, Riddell SR: Therapy of relapsed leukemia after allogeneic hematopoietic cell transplantation with $\mathrm{t}$ cells specific for minor histocompatibility antigens. Blood 2010;115:3869-3878.

-98 Greiner J, Bullinger L, Guinn BA, Dohner H, Schmitt M: Leukemia-associated antigens are critical for the proliferation of acute myeloid leukemia cells. Clin Cancer Res 2008;14:71617166.

99 Quintarelli C, Dotti G, De Angelis B, Hoyos V, Mims M, Luciano L, Heslop HE, Rooney CM, Pane F, Savoldo B: Cytotoxic T lymphocytes directed to the preferentially expressed antigen of melanoma (PRAME) target chronic myeloid leukemia. Blood 2008;112:1876-1885.

100 Rezvani K, Yong AS, Mielke S, Savani BN, Musse L, Superata J, Jafarpour B, Boss C, Barrett $\mathrm{AJ}$ : Leukemia-associated antigen-specific $\mathrm{T}$ cell responses following combined PR1 and WT1 peptide vaccination in patients with myeloid malignancies. Blood 2008;111:236-242.

101 Greiner J, Schmitt A, Giannopoulos K, Rojewski MT, Gotz M, Funk I, Ringhoffer M, Bunjes D, Hofmann S, Ritter G, Dohner H, Schmitt M: High-dose RHAMM-R3 peptide vaccination for patients with acute myeloid leukemia, myelodysplastic syndrome and multiple myeloma. Haematologica 2010;95:1191-1197.

102 Schmitt M, Schmitt A, Rojewski MT, Chen J, Giannopoulos K, Fei F, Yu Y, Gotz M, Heyduk M, Ritter G, Speiser DE, Gnjatic S, Guillaume P, Ringhoffer M, Schlenk RF, Liebisch P, Bunjes D, Shiku H, Dohner H, Greiner J: RHAMM-R3 peptide vaccination in patients with acute myeloid leukemia, myelodysplastic syndrome, and multiple myeloma elicits immunologic and clinical responses. Blood 2008;111:1357-1365. 